\title{
POJMOVNOST APOFATIČKE TEOLOGIJE: DIONIZIJE AREOPAGITA O HIMNIČKOM POREKLU FILOZOFSKIH POJMOVA
}

Ovaj rad posvećen je ispitivanju promene u razumevanju filozofske pojmovnosti kod Dionizija Areopagita. Da bi filozofija kao oslovljavanje Boga (teologija) mogla biti opravdana u apofatičkom duhu, Areopagita napušta dotadašnje matrice i uvodi nov tip pojmova, koji poreklo imaju u sveštenim himnama. Veza himničkog jezika i jezika filozofije biće predmet analize u radu, a sa naglaskom na temeljnim pojmovima - božanskim imenima. Analiza pokazuje da ovi pojmovi napuštaju semantičke i logičke uzuse tradicije, te umesto njih sa istim funkcijama uvode bezimenost i mnogoimenost.

Ključne reči: Dionizije Areopagita, apofatika, filozofski pojam, himne, teologija.

Odnos filozofije i hrišćanske misli razvija se još od prvih vekova hrišćanstva. Prirodno, u pokušaju zasnivanja jedne hrišćanske - a ne filozofske teologije, filozofski uzori i modeli, uključujući tu i pojmovna rešenja, nametali su se kao nezaobilazni sagovornik u naporu da se artikuliše misao o Onom čija suština izmiče svakom znanju. Bilo da se spram paganske filozofije postavljala antagonistički, ili je pokušavala da je inkorporira u sopstvena kretanja, hrišćanska teologija u nastajanju izmenila je način na koji se filozofija do tad razumevala, a to se posebno odrazilo na njene centralne pojmove.

Takav slučaj predstavlja i teologija (Pseudo)-Dionizija Areopagite, nepoznatog autora iz VI veka, koji je pisao pod pseudonimom prvog vladike crkve u Atini. Corpus Dionysiacum odredio je hrišćansku misao kako na istoku, tako i na zapadu, a u savremenoj filozofiji sve češće je revitalizovan (Coakley, 2009: 13-14). U ovom radu razmotrićemo promenu filozofske pojmovnosti - njenog oblika, porekla i karaktera - kakvu predlaže i sprovodi Areopagita. Cilj rada, u užem smislu, razmatranje je veze jezika filozofije i sveštenih himni, u kojima on, prema Areopagiti, nalazi svoje poreklo i legitimaciju.

*unapopovic@ff.uns.ac.rs 


\section{STATUS FILOZOFSKOG POJMA U TEOLOGIJI AREOPAGITE}

Apofatička, kao i katafatička teologija Dionizija Areopagite bitno počivaju na poznavanju i upotrebi klasične grčke filozofije, pre svega logike. U oba slučaja, a u skladu sa osnovnim uverenjem Areopagite o radikalnoj nemogućnosti čoveka da stekne znanje o Bogu, razumske sposobnosti čoveka koriste se za njihovu sopstvenu kritiku, a posredno - ali i ključno - za otvaranje novog tipa znanja (Stang, 2012: 124-125). Taj novi tip znanja zapravo i nije znanje u pravom smislu reči; kao što je poznato, to je znanje o sopstvenom neznanju, znanje o nemogućnosti znanja, znanje o granicama saznajnog domašaja ljudskog bića. U vrednosnom pogledu, takvo znanje Areopagita ceni više: u sokratovskom maniru, znati da ne znamo bolje je nego pogrešno verovati da znamo. Ali i više od toga: granica postavljena između znanja i neznanja, a u korist neznanja kao višeg znanja, iako se ne može preći, dinamični je limes koji ipak opisuje, opasuje i naznačava područje neznanja. Iako ga ne može posednuti i pokoriti, ljudski razum takvo nedostupno znanje ipak može naslutiti. Uvažavanje takvog znanja je zahtev koji Areopagita udružuje sa hrišćanskim prizivom na svesni i žuđeni odnos čoveka prema Bogu.

U oba slučaja, dakle, Areopagita upisuje svoj credo o neznanju kao višem znanju direktno u iskivanje novog smisla teologije, sada kao hrišćanskog, a ne samo filozofskog oblika diskursa o osnovama stvarnosti - onom božanskom. Areopagita, dakle, neposredno interveniše nad ustaljenim oblicima smislenog ljudskog govora i rezonovanja, koristeći logiku kako bi opovrgnuo apsolutno važenje tako organizovanih i artikulisanih znanja. Jezik kojim se koristi, stoga, bitno odstupa kako od tradicionalne filozofije, tako i od dotadašnje hrišćanske misli: taj jezik bitno je metodski opredeljen, jer njegov izraz zavisi od načina njegove upotrebe. Posledica ovog Areopagitovog gesta je i veoma zanimljiva promena u karakteru filozofske pojmovnosti.

Tako, u slučaju apofatičke teologije, Areopagita koristi logičku operaciju negiranja kako bi izmenio smisao veze subjekta i predikata afirmativnog iskaza: apofatika će iskaz „Bog nije dobar” pretpostaviti iskazu „Bog je dobar” upravo zbog toga što subjekt Bog i predikat dobro ne odgovaraju jedan drugom. Razlog tome je, po Areopagiti, činjenica da ljudsko biće sve svoje pojmove, pa čak i one koji se na prvi pogled čine primerenim označavanju osobina i karakteristika Boga, iskiva polazeći od sopstvenih ontoloških okvira - okvira stvorenja, kao i od okvira stvorenog sveta sa kojim mahom stupa u kontakt i čijem su saznanju njegove sposobnosti dovoljne (Stang, 2012: 154-155). Jednostavnije rečeno, konotacija predikata dobro vezana je i jedino može biti vezana za osobine stvorenja. Samim tim, pripisati takav predikat Bogu značilo bi pripisati mu osobine stvorenja, što 
sigurno nije ispravno. Posledično, ukoliko uz subjekt termin Bog treba dodati još neki termin, u funkciji predikata ili njoj sličnoj, takvo šta podrazumeva pojmovnost drugačijeg tipa i karaktera od uobičajenog.

Katafatička teologija, koja počiva na uvidima stečenim apofatičkim putem, problem neadekvatnosti Boga kao subjekt-termina i bilo kog termina u funkciji predikata rešava principijelnom izmenom predikata. Izmena se vrši uvođenjem prefiksa pre- (pro) ili nad- (hyper), pa tako umesto dobar dobijamo predobar, umesto sušti nadsušti i slično (Stang, 2012: 122). U pitanju su, dakle, određenja koja sopstvenom strukturom - sintaksički koliko i semantički - upozoravaju da na delu nisu uobičajene reči, temini i predikati, već specijalni pojmovi čija referencija ima samo jednog referenta, samog Boga. Svi ovi pojmovi, dakle, denotiraju isto biće, a razlike $u$ njihovim konotacijama odgovaraju apofatičkom stavu o nemogućnosti potpunog znanja suštine Boga. Ni jedan od tih pojmova, naime, ne iscrpljuje celinu smisla bića Boga, iako ga svaki zahvata u celini - a ne u delu (Ареопагит, 2015: 18). Iako ga ni jedan zapravo ne promašuje, ni jedan ga ni ne pogađa u potpunosti.

Apofatički ton utkan u katafatičko rešenje vidi se i u činjenici da ovi pojmovi, iako naizgled postavljeni kao pozitivna određenja osobina Boga, zapravo to nisu. Ni u jednom od takvih slučajeva ljudsko biće nije u stanju da iscrpi čak ni konotacije pojma kojim se koristi, a razlog tome opet je činjenica da nam je Bog nespoznatljiv. Dakle, ni za jedan od ovakvih pojmova nije moguće dati definiciju i potpuno određenje; mi, zapravo, ne znamo šta oni tačno znače (Louth, 1989: 78). Jedino što znamo je da oni označavaju osobine Boga koje mi ne razumemo - ili, preciznije rečeno, da označavaju ono što je kod Boga analogno, to jest, disanalogno osobinama koje poseduju stvorenja (Stang, 2012: 124). Stoga je jasno da i na katafatičkom putu baratamo sa pojmovima sasvim novog tipa i karaktera.

Štaviše, za Areopagitu problem nisu samo konkretni pojmovi, termini koji bi mogli imati funkciju predikata u iskazu čiji je subjekt-termin Bog. Mnogo veći problem za njega predstavlja sama iskazna struktura, konstitutivna za način ljudskog mišljenja: samo pripisivanje predikata subjektu problematično je zbog toga što pretpostavlja ograničenje subjekta predikatom. Subjekt/predikat matrica, dakle, neprimenljiva je na Boga, budući da njega nije moguće ni odrediti, ni ograničiti. Međutim, ukoliko je tako, koji oblik veze treba pripisati subjekt-terminu i novim „predikatima”? Na koji način funkcioniše njihova veza?

Rešenje koje nudi Areopagita karakteristično je za njegovu misao i u velikoj meri odstupa od potonjeg rešenja, koje se već tada počelo razvijati razlikovanja kategorija i transcendentalija. Umesto transcendentalija i njima 
imanentne nekategorijalne „logike” eksplikacije (explicatio), odnosno analoškog odnosa prema prvom od svih pojmova (esse), Areopagita nudi - mnogoimenost! „I tamo opet, silazeći od gornjeg ka donjima, reč se proširuje ka mnoštvu, odgovarajući mu" (Ареопагита, 2010: 182), tvrdi on.

Ispravni način da se termin Bog poveže sa drugim terminima je, dakle, da se novi ,predikati” prepoznaju kao negacija predikata, kao ono što nije predikat odnosno, kao ono što je ime (i što može imati samo funkciju subjekt-termina). Unutrašnja struktura govora o Bogu, odnosno teologije, tako je mnogo bliža modelu iskaza identiteta $(\mathrm{A}=\mathrm{A})$ nego modelu kategorijalnog iskaza koji predikat pripisuje subjektu, a što ga ističe Aristotel. U slučaju iskaza identiteta predikat zapravo ne postoji, nego i on predstavlja (ravnopravno) ime istog referenta na koji upućuje subjekt-termin. Njihov odnos, stoga, znači ustanovljavanje da dve reči, dva imena, imaju istu denotaciju, slično kao u slučaju povezivanja imena sa nadimkom (Aristokle je Platon). Ovde, dakle, iskaz funkcioniše kao uspostavljanje identiteta između dva termina, pri čemu nema njihovog međusobnog ograničavanja.

Primat modela identiteta, iako donekle očekivan s obzirom na nasleđe Svetog Avgustina, u slučaju Areopagite nipošto nije olako prihvaćen. O tome svedoči upravo naglašena mnogoimenost: Areopagita, naime, ne pristaje na formalno-sadržinsku puninu Avgustinovog rešenja, koje na pozadini starozavetnog Ja sam onaj koji jesam uz subjekt-termin Bog ističe termin esse (biti) kao pravo filozofsko ime Boga (Augustin, 2009: 248; Popović, 2018: 17-18). Avgustin, dakle, vrši pročišćenje i restrikciju mnogih (kandidata za) imena Boga na jedno (esse), koje stoji u osnovi svih ostalih; veza sa potonjim transcendentalijama sada se može jasno uočiti. Areopagita, međutim, odbija redukciju i takvo filozofsko svođenje mnogih na jedno, te umesto toga promoviše mnogoimenost, kao potencijalno beskonačno ulančavanje imena Boga, od kojih je, konačno, i sam subjekt-termin Bog samo jedno u nizu.

Tako čitamo:

Mnogoimen je pak On zato što Ga predstavljaju da govori: 'Ja sam Sušti' (Post. 3, 14), 'Život' (Jn. 14, 6), 'Svetlo' (Jn. 8, 12), 'Bog' (Post. 28, 13), 'Istina' (Jn. 14, 6), i u isto vreme ti bogomudri opevaju Uzrok svega, pozajmljujući imena iz svega Njime pričinjenog, kao ono: 'Dobar' (Mt. 19, 17), 'Prelep' (Ps. 26, 4), 'Mudri', 'Ljubljeni' (Is. 5, T), 'Bog bogova' (Ps. 49, 1), 'Gospod gospode' (Jes. 135, 3), 'Svetinja Svetih', 'Večni' (Drugoknj. 33, 27), 'Sušti' (Izl. 3, 14) i 'Uzrok vekova', 'Davalac života', 'Premudrost' (Prič. 9, Otkr. 1, 30), 'Um' (1 Kor. 2, 16), 'Reč' (Jn. 1, /), 'Svedočeći', 'Koji je ovladao otpre svim skrovištima svakog znanja' (Kol. 2, 3), 'Sila', 'Vlastelin', 'Car carujućih', 'Starodnevni' (Dan. 7, 9), 'Nestareći i Neizmenjiv', 'Spasenje', 
'Pravednost' (Jer. 23, 6), 'Osvećenje' (Otkr. 1, 30), 'Izbavljenje', 'Koji prevazilazi sve veličine' i prisutan 'U disanju tankom'. (Ареопагит, 2015: 15)

Kako vidimo, ulančavanje mnogih imena Boga, odnosno božanska mnogoimenost, $u$ navedenom citatu potvrđena je istim autoritetom kao i Avgustinova redukcija - autoritetom Svetog Pisma (Anderson, 1965: 20). Ipak, u ovom slučaju ne dobijamo ništa podložno zakonima logike; naprotiv, dobijamo regressus ad infinitum koji, što prepoznaje i sam Aristotel, ukida mogućnost znanja. Svakako, to nije slučajno. Areopagitova mnogoimenost je, naime, samo druga strana bezimenosti Boga: „Znajući to, bogoslovi Ga opevaju kao bezimenog, te kao saobraznog svakom imenu" (Ареопагит, 2015: 14).

Iako sam Areopagita bezimenost pojašnjava iznova se pozivajući na Sveto Pismo, njena suština je bitno apofatička. Bezimenost vodi ka konačnom rušenju svih logičkih kategorija - sada i mogućnosti da se pojmovi koji denotiraju Tvorca shvate kao imena, uključujući tu i odlikovani subjekt-termin Bog. Štaviše, kako pokazuje Endrju Laut (Andrew Louth), funkcija božanskih imena zapravo i nije imenovanje, već proslavljanje (hymnein) Boga - zato su ona himnička (Louth, 1989: 79). Bezimenost je signal da se, uprkos mnogim imenima kojima se Tvorac može naznačiti, ovaj njima ipak ne može ni znati ni zahvatiti - ni jednim imenom zasebno, ni svima njima zajedno. ${ }^{1}$ Akumulacija mnogih imena, dakle, nikada ne može biti dovršena, jer denotirano uvek izmiče.

Njena uloga, stoga, mora biti drugačija. Čini se da je ona naznačena $u$ navedenim citatima, u kojima se, pored samog Gospoda koji govori Svetim Pismom, kao imenovaoci Tvorca navode i bogomudri, odnosno bogoslovi. Oni, međutim, opevaju; njihov logos nije logički, već himnički. Shodno tome, bezimena mnogoimenost Boga ne funkcioniše po principima analitike i dijalektike, već po principima pevanja (ali ne i teorijske poetike). Drugim rečima, principijelno otvorena mnogoimena bezimenost $u$ iskazivanju neiskazivog i nepojmljivog Gospoda ima ulogu veze - logičku ulogu, ali tako da, za razliku od nekategorijalno logičkih transcendentalija, unapred isključuje svaku logiku i racionalnost (Ареопагита, 2010: 179-180). Veze se tu iskivaju (himno)poetski.

\footnotetext{
1 Slično tome Avgustin argumentiše da poznavanje imena Boga (Deus) ne znači znati njegovu prirodu (Augustine, 1995: 19).
} 


\section{HIMNOPEVANJE I FILOZOFSKA POJMOVNOST}

Kako je prethodno pokazano, teologija Areopagite apofatički ide protiv pojmovnosti i mišljenja ustaljenih u dotadašnjoj filozofiji. Areopagita to čini kako u pogledu logičkih veza (model predikacije, model identiteta), tako i u pogledu njima povezanih termina (ni predikat, ni subjekat / ni osobina, ni ime). Posmatrano iz perspektive tadašnje logike, Areopagita je time ukinuo svaki poznati i dopušteni tip filozofskog pojma.

Ipak, kako je pokazano, suspenzija starih ide ruku pod ruku sa uvođenjem novih pojmova - pojmova poput predobar ili prelep, novih (mnogo)imena Boga. Štaviše, uz novi tip pojmova ide i novi tip pojmovnih veza: kako smo videli, himnopoetskih. I dodatno: navedeni mnogoimeni citat pored ovih pojmova, a uz legitimaciju najvišeg autoriteta, u igru vraća i (naizgled) obične pojmove, poput Svetlo, Istina, pa čak i Dobar. Ali, kako je to moguće, ako je odbacivanje upravo takvih pojmova bilo prvi korak Areopagitovog apofatičkog hoda? Prividna i neslučajna kontradikcija razrešava se vrlo jednostavno: ovi pojmovi nisu problematični jer njihovo poreklo nije od ovog sveta - oni su dar i milost odozgo, koliko je to i samo Sveto Pismo. Rečju, oni ne potiču od stvorenja, već iz svešteničkog i Svetim Duhom nadahnutog himnopevanja: rečima Čarlsa Stanga (Charles M. Stang), pravilna upotreba božanskih imena podrazumeva promenu onog ko ih koristi (Stang, 2012: 156).

Areopagita kaže: „Sasvim ne odgovara da sme da se kaže ili pomisli nešto o nadsuštastvenoj i skrivenoj božanstvenosti, sem toga što nam je bogovidno očitovano sveštenim izrekama" (Ареопагит, 2015: 6). One nas, međutim, uče sledećem: „I naći ćeš da je svako, može se reći, svešteno pesmopevanje bogoslova, objašnjavanje i opevavanje otkrivajućih napredovanja Bogonačela, što pripremaju božanska imena" (Ареопагит, 2015: 9). Božanska imena su, dakle, pripremljena pesmopevanjem bogoslova, a ova su, pak objašnjavanja i opevavanja samih Bogonačela.

Komplikovani citat sada je moguće donekle razlučiti. Pod pesmopevanjem bogoslova Areopagita misli na diskurs karakterističan za sveštenu službu, ponajpre za liturgiju; no, više od njegove konkretne primene, ovde se cilja na specifičnost jezika crkve, koji se razlikuje od svakodnevne upotrebe istog tog jezika. Iako se, recimo, u oba slučaja radi o grčkom, za Areopagitu oni su različitiji nego što bi to bilo koja dva govorna jezika mogla biti. Pesmopevanje je govor nadahnut milošću Gospodnjom i podstaknut verom, govor čiji su sagovornici čovek i Bog, govor kome i semantika i sintaksa dolaze odozgo. Samim tim, on se radikalno otcepljuje 
od svog prividnog parnjaka, istog tog grčkog jezika upotrebljenog u razgovoru dva čoveka.

Pesmopevanje je, dakle, praksa analogna nastanku Svetog Pisma: ako je ono reč Božja (kroz proroke i jevanđeliste) upućena čoveku, pesmopevanje je odziv tom pozivu, odgovor čoveka reči Božjoj (Stang, 2012: 119-120). Taj odgovor, međutim, čoveka vodi preko njegovih prirodnih granica, te je i sama činjenica da je on moguć pokazatelj upliva više sile, milosti koja takav razgovor drži otvorenim. Pesmopevanje, tako, počiva na Svetom Pismu i principijelno je otvoreno za svo sveštenstvo (pa, u krajnjem, i za svakog vernika), a ne samo za odabrane (proroke).

Ono što je za nas zanimljivo, međutim, veza je između pesmopevanja sa jedne, te božanskih imena sa druge strane. Kako smo videli, božanska imena pripremljena su pesmopevanjem; ona, stoga, ne mogu biti ista. Božanska imena su nižeg ranga i reda u odnosu na pesmopevanje, i svoj izvor nalaze u pesmopevanju koje ih priprema. Sa druge strane, kako smo pokazali ranije, božanska imena su najviši domašaj mišljenja koje stremi ka Bogu, a oslanja se na ljudske sposobnosti rečju, hrišćanski opredeljene filozofije. Dakle, ono što je u filozofskom smislu najviše, iz perspektive Svetog Pisma kao uzora ispravnog govora o Bogu (jer Bog tu sam o sebi progovara) ispostavlja se kao najniže; platonički rečeno, kao trostruko udaljeno od uzora. Ipak, božanska imena mesto su susreta dve ose, čvorišta ukrštanja ljudskog hoda ka gore i božanskog proishođenja ka dole. Time se još jednom potvrđuje da je za Areopagitu jedina istinski neprihvatliviva opcija misaono kretanje po horizontali, zarobljenost okvirima smisla i promišljanja stvorenja.

U konkretnom, za filozofiju bi to značilo sledeće: ukoliko je ona istinska i radikalna, ona se mora upustiti u istraživanje poslednjih osnova stvarnosti; takva filozofija onda je i teologija, jer je Bog onaj od kog je sve poteklo. Ipak, prateći taj impuls, filozofija i ljudska racionalna misao nužno će se sudariti sa svojim granicama. U nemogućnosti da te granice samostalno pređe, filozofska misao mora se otvoriti za ono što iz prostora nemogućeg znanja dolazi samo po sebi, odnosno ona mora da crpi iz himni i pesmopevanja. U konačnom, ona to može samo u posebnim slučajevima - upravo u slučajevima filozofskog govora o Bogu, odnosno božanskih imena.

Filozofski pojmovi, međutim, time ne postaju reči sveštenih himni. Naprotiv, oni ostaju - ili bolje rečeno, tek tako postaju - filozofski pojmovi; svakako, drugačije i do tad neviđene provinijencije. Božanska imena pripremljena $s u$ pesmopevanjem i nisu mu identična. To znači da se reči koje prepoznajemo kao ovakve specijalne filozofske pojmove de facto zatiču u sveštenim himnama i da se otuda preuzimaju. Ipak, kada su deo himničkog opevanja, one funkcionišu u 
njegovom registru i imaju himnopoetski karakter, dok, kada se iz pesmopevanja preuzmu u filozofski diskurs, one prelaze u drugi registar i dobijaju drugačiji filozofski karakter. Pronalazeći kandidate za božanska imena u himnama, filozof/teolog bi, dakle, trebalo da ih uvaži kao istinska imena Boga, a potom da ih kao takve razmotri i objasni koristeći se, koliko je moguće, filozofskim sredstvima. To čini i Areopagita; tako se spis $O$ božanskim imenima sastoji od niza razmatranja pojedinih imena, poput Savršeni, Jedan, Dobro, Lepo, Život i slično.

Ipak, pošto potiču iz nesvakidašnjeg izvora, božanska imena kao filozofski pojmovi specifična su i razlikuju se od pojmova tipičnih za filozofiju do Areopagite. Specijalni filozofski karakter božanskih imena Areopagita imenuje simbolima, pod čim nikako ne smemo misliti na danas uobičajeni smisao te reči. Naprotiv, simboli su za Areopagita konačni karakter njegovog sopstvenog izlaganja, čiju je mogućnost inače doveo u pitanje (Ареопагит, 2015: 12): „Koliko je moguće, i sada se koristimo govoreći o božanskom, nama dostupnim simbolima” (Ареопагит, 2015: 11).

Šta, onda, zapravo znači da su filozofski pojmovi apofatičkom teologijom pokazani kao simboli? U prvom redu, to znači njihovu legitimaciju; filozofija, dakle, bar u ovim slučajevima ne zavisi od ograničenja ljudskog saznanja, već se konstituiše na čvrstim (božanskim) temeljima. Svakako, ona više ne može da operiše na način tradicije i od nje će se bitno razlikovati. Ipak, u suprotnom ukoliko bi se zadržala u svojim starim okvirima - ona ne bi odolela kritici. Dakle, sebi identična, filozofija je nemoguća; preobražena, ona napušta sebe da bi sebe zadobila.

Drugo, i za nas ovde mnogo zanimljivije, to znači da su filozofski pojmovi dvostruko konstituisani, da njihova pojmovna struktura ukršta dva pojmovna karaktera - filozofski i himnopoetski. Ili, drugačije, reći da je filozofski pojam simbol znači uvideti da on pored svog uže filozofskog karaktera i načina operisanja ima i u njega upisani himnopoetski karakter, opredeljen poreklom božanskih imena iz pesmopevanja. Iako reč poput Sušti (ousia), kada se jednom preuzme iz pesmopevanja i postavi kao božansko ime, zadobija drugačiji, filozofski karakter, ona i dalje upućuje natrag na svoje poreklo, a time otvara filozofski pojam iznutra. Kako smo videli, bez ove konstitutivne i čvrste veze sa pesmopevanjem filozofski pojmovi propadaju i semantički i sintaksički i logički.

Simbol je, stoga, naziv za ovaj novootkriveni dvostruko ukršteni (horizontalno $i$ vertikalno postavljeni) karater filozofskih pojmova. Areopagita poziva: 
usmeravamo se na susret sa zrakama, koje nam sijaju iz sveštenih reči, njihovim svetlom znanim za bogonačelne pesmopeve, koje su im od svetla posvećivane, nadahnute sveštenim pesmoslovljem, na posmatranje srazmerno od njih nam darovanih bogonačelnih svetala, za opevavanje blagodatnog načela svakog svešteničkog svetlojavljanja ako, kako je ono samo sebe izrazilo u sveštenim izrekama. (Ареопагит, 2015: 9)

Svetlo je u datom slučaju svetlo poznanja, ali ne ovozemaljsko, već tavorsko svetlo. Reč je, dakle, o inače za čoveka zatvorenom poimanju, koje se samostalno projavljuje i otkriva - samo sebe izražava u sveštenim izrekama. Himnopoetska reč je, tako, reč kroz koju probija božansko svetlo - reč koja sija $i$ svetli. Filozofska reč, božansko ime poreklom iz pesmopevanja, tako bi takođe trebalo da bude svetlonosna, makar ona to bila u manjem stepenu od himnopoetske reči. $^{2}$ Ipak, svetljenje obe ove reči, važno je primetiti, odvija se putem susreta sa njihovim zrakama; svetljenje je konstituisano mnogim zracima nadumnog svetla, ne samo jednim snopom svetlosti (Ареопагита, 2010: 180; Louth, 1989: 93-94).

U slučaju himnopoetskih reči, lako je zaključiti da se ovom mnogozračnošću njihovom smera na preobilje značenja koje takva reč nosi, to jest, na nemogućnost da se svi pravci značenja koje ona otvara iscrpe i razlikuju (Ареопагита, 2010: 182). Značenje himnopoetske reči neiscrpno je i opire se bilo kakvom pokoravanju. Drugačije, napokon, ne bi ni moglo biti, jer takvo značenje zapravo ne pripada ljudskim rečima, koje su ograničene već vrlinom toga da pripadaju domenu stvorenog. U himnopoetskim rečima dešava se nemoguće spajanje božanskog (sadržaja) sa formom koju ono unapred prevazilazi; mnogozračnost, odnosno neiscrpna mnogoznačnost takvih reči prirodna je posledica njihovog karaktera.

Šta to, međutim, znači za filozofsku reč? Ako je ona simbol, da li je i ona mnogozračna? Razlozi za pozitivan odgovor na to pitanje već su navedeni. Najpre, filozofska reč kao simbol iznutra je otvorena upućivanjem na svoje poreklo, te otuda ona izvesno ne može biti redukovana na jednoznačnost. Sa druge strane, poreklo fillozofske reči u himnopevanju navodi na misao da ona bar u nekoj meri preuzima karakteristike himnopoetske reči.

2 Iako odbacuje neoplatoničke ideje o kontinuitetu emanacije bića od Boga na niže, Areopagita zadržava isti model mišljenja kada je reč o znanju i svetlosti. Svetlost se, dakle, prenosi od Boga ka bićima, tako da svako od bića postaje osvetljeno i svetleće, prenoseći božansku svetlost dalje, ka nižim bićima na lestvici (Louth, 1989: 75). 
Prema našem sudu, a prateći ova dva razloga, konačni karakter simbola kao filozofskih pojmova bi se mogao odrediti na sledeći način. Simboli nisu mnogozračni na način na koji su to himnopoetske reči. Filozofske reči - budući filozofske - pre ne mogu da ponude značenja o božanskom, nego što nude mnoštvo takvih značenja. Njihov karakter, dakle, više odgovara bezimenosti nego mnogoimenosti Boga: filozofske reči svetle, ali tako što zaslepljuju. Smisao koji se od pesmopevanja sprovodi do jezika filozofije za svoje izražavanje tu nalazi još manje pogodnu (jezičku) formu, pre svega zbog neraskidive veze filozofije i logike, odnosno razuma.

Svetlost filozofskih reči ne može se zahvatiti njima samima. Ako se pokušaju razumeti ustaljenim filozofsko-logičkim sredstvima, polazeći od forme diskursa čiji su deo, one će ostati nejasne, neplodne, prazne. Ako se, međutim, njihovo razumevanje vodi njihovim smislom (sadržajem), koji se ne može definisati i nije jasan, prividni mrak će se apofatički pokazati kao božanski primrak, kao svetlo višeg reda. U tom smislu filozofske reči najpre zaslepljuju i posreduju neznanje i nepoimanje. Rečima Areopagite: „Kao i sada ulazeći u božanski primrak, naći ćemo ne kratkorečivost već potpuno bezrečje i nemišljenje" (Ареопагита, 2010: 182). Ipak, ispravno postavljene, otkrivaju se kao svetlonosne - kao nosioci tavorskog svetla bogopoznanja. Povratno, takav zaključak potvrđuje apofatički karakter celine Areopagitove teologije, bez obzira na njeno uže razdvajanje na apofatičku i katafatičku (Louth, 1989: 88, 96).

Ipak, bezimenost Boga ide uz njegovu mnogoimenost. Tako je i u slučaju filozofskih reči. Iako je njihov primarni karakter bliži bezimenosti, ipak se i mnogoimenost očituje kao drugi aspekt preobraženog jezika filozofije. Mnogoimenost ovde, međutim, svoje mesto nalazi u međupojmovnim vezama, kao intervencija i negacija ustaljenih logičkih identitarnih i predikativnih matrica. Božanska imena povezuju se mnogoimenim ulančavanjem bez projektovanog kraja, te je bilo koji drugi način njihovog povezivanja - poput onog koji nalikuje starim oblicima filozofskog diskursa, na primer, Bog je predobar - valjan, smislen i razumljiv samo polazeći od takve pozadine.

Mnogozračnost himnopoetskih reči se, tako, u njihovoj filozofskoj posledici projavljuje ukrštanjem više zraka, odnosno više filozofskih pojmova, bez unapred date ili razumski odredive hijerarije ili zadatog poretka kretanja tog ulančavanja. Kao u slici koju Areopagita daje prilikom tumačenja pojma dobro, u takvom filozofskom govoru mi kao da se nalazimo u prostoriji osvetljenoj sa više svetiljki (Ареопагит, 2015: 22-23). Svaka od njih daje zasebno svetlo, ali je svetlo koje iskušavamo $\mathrm{u}$ prostoriji neraskidiv spoj svih njihovih svetljenja $\mathrm{i}$ deluje 
homogeno. Pojedinačna svetiljka može se izneti van prostorije, pa tako i sagledati u sopstvenom sijanju, ali njeno udruživanje sa drugim takvim svetljenjima izmiče analitici pogleda i nameće vidljivost drugačije vrste.

\section{ZAKLJUČNA (FILOZOFSKA) REC̆}

Razmatranja promene karaktera filozofske pojmovnosti kod Dionizija Areopagite zaključujemo sa nekoliko ograda. Najpre, zbog obima rada, ovde nismo bili u prilici da detaljno analiziramo sva božanska imena o kojima on govori, kao ni njihove specifičnosti. Cilj je, pre, bio da se ocrta specifična veza himni i jezika filozofije, te da se unutrašnja konstitucija filozofskih pojmova pokaže u svom preobraženom vidu. U tom pogledu, fokusirana veza implicira dodatna razmatranja kako u pogledu odnosa poezije i filozofije u antičkoj (paganskoj) misli, tako i u smeru razmatranja odnosa božanskih imena i drugih pojmova filozofije, onih koji nisu direktna oslovljavanja Boga. Za takav poduhvat ovaj rad može predstavljati pripremnu studiju.

Još jedan izuzetno važan pravac razvijanja teme preobražaja filozofske pojmovnosti kod Areopagite vodi ka neoplatonističkom nasleđu, čiji je on nesumnjivi baštinik. Mnoga od božanskih imena, naime, zapravo su stari neoplatonički pojmovi (Louth, 1989: 81-82). Ipak, oni kod Areopagite ne ostaju neizmenjeni: kako bi postali božanska imena u novom ne-neoplatonističkom ključu, ti pojmovi moraju i sami biti preobraženi - tačnije, pokazani u svom sakralnom poreklu, što Areopagit na mnogim mestima i nastoji da učini (Ареопагит, 2015: 86, 105, 127-128). Specifičnost prekrajanja takvih pojmova, te slabosti i snaga Areopagitove argumentacije, međutim, tema su koja zahteva zasebnu studiju.

Konačno, u razmatranju božanskih imena ne treba zanemariti njihovu primarnu ulogu, koja se ne tiče samo sticanja i artikulacije znanja, već i duhovnog uzdizanja duše. Pošto su ova imena poreklom himnička, ona aktivno čoveka usmeravaju ka Bogu, odnosno ka preobraženju duše (ne samo pojmova). Božanska imena, dakle, ne treba da o Bogu samo nešto kažu i pokažu, već da pre svega iniciraju put duše ka Bogu (Louth, 1989: 80). U tom pogledu, moglo bi se reći da novi jezik filozofije kod Areopagite ima performativni karakter - da, upotrebljavajući ga, mi pre delamo rečima, nego što tvrdimo ili odričemo neko znanje. U potvrdu te teze govori i izvanredna studija Danijela Krugera (Daniel Krueger), koja pokazuje direktne veze između prakse pisanja i oformljavanja sopstva posebno u hagiografskoj i himničkoj literaturi IV i V veka (Krueger, 2004: 193-194). Pisanje se, tako, ispostavlja kao novi oblik religiozne prakse, pa je 
utoliko za očekivati i da se u slučaju teološkog spisateljstva jezik razume kao oruđe samooblikovanja shodno cilju teoze.

Areopagitova preimenovanja (Ареопагита, 2010: 181) filozofskih, odnosno razumom stečenih pojmova, napokon, moraju se tumačiti shodno celini i duhu njegove misli (Coakley, 2009: 17). Iako religiozno usmerena, ona i danas mogu postati značajno ogledno mesto za preispitivanje smisla i mogućnosti izraza koji dopušta i ustanovljava jezik filozofije - mesto koje svedoči o njegovim potencijalima. Utoliko je primereno da analizu završimo upravo Areopagitovim rečima: „Otuda koliko god da se uznosimo ka uzvišenijem, toliko se reči, sažimanjima umnih, sužavaju” (Ареопагит, 2010: 182).

\section{Una Popović}

\section{CONCEPTUALITY OF APOPHATIC THEOLOGY. DIONISIOS THE AREOPAGITE ON HYMNIC ORIGIN OF PHILOSOPHICAL CONCEPTS}

\section{Summary}

This paper is about the changed understanding of philosophical concepts in Dionisios the Areopagite. In order to justify philosophy as a speech about God (theology) in the apophatic manner, Areopagite discards the usual conceptual matrix and creates a new type of concepts, whose origin is in eclessial hymns. The relation between the language of hymns and language of philosophy is the subject of my analysis, which will be focused on the case of key concepts - divine names. Analysis shows that these concepts do not function according to semantical and logical rules, but instead of those, although with the similar purpose, introduce namelessness and multinamedness (of God).

Keywords: Dionisios the Areopagite, apophatics, philosophical concept, hymns, theology.

\section{LITERATURA}

Anderson, J. F. (1965). St. Augustine and Being: A Metaphysical Essay. The Hague: Martinus Nijhoff.

Свети Дионизије Ареопагит. (2010). О тајанственом богословљу. У: Дела светог Дионизија Ареопагита. Београд: Мирослав.

Дионизије Ареопагита. (2015). О божанским именима. Ниш: Међународни центар за православне студије/Центар за византијско-словенске студије Универзитета у Нишу.

Augustin, A. (2009). Trojstvo. Split: Služba Božja.

Augustine. (1995). De Doctrina Christiana. Oxford: Clarendon Press. 
Coakley, S. (2009). Introduction - Re-Thinking Dionysius the Areopagite. In: Coakley, S., Stang, Ch. M. (eds.) (2009). Re-Thinking Dionysius the Areopagite. Oxford: Wiley-Blackwell. 13-33.

Krueger, D. (2004). Writing and Holiness. The Practice of Authorship in the Early Christian East. Philadelphia: University of Pennsylvania Press.

Louth, A. (1989). Denys the Areopagite. London: Continuum Press.

Stang, Ch. M. (2012). Apophasis and Pseudonymity in Dionysius the Areopagite. "No Longer I". Oxford: Oxford University Press. 